\title{
Pengaruh Mindful Parenting terhadap Stres Pengasuhan pada Guru Wanita yang Memiliki Anak Sekolah Dasar
}

\author{
Unique Nur Alifa Putri *, Andhita Nurul Khasanah \\ Prodi Psikologi, Fakultas Psikologi, Universitas Islam Bandung, Indonesia. \\ *uniquenura4@gmail.com, andhita.khasanah@gmail.com
}

\begin{abstract}
Mindful parenting is a parenting skill that attentive and full of awareness, and accepting children without judgment. By implementing mindful parenting, parents will avoid abusive parenting and reduce parenting stress levels. This study aims to see the effect of mindful parenting on parenting stress. Teachers have a heavier burden because they have to take care of children and work with different systems during the pandemic. Having children in elementary school is also a challenge for mothers, where they need direction from parents and help in learning. This study uses the causality method and is a population study with a subject of 49 mothers who work as private elementary school teachers who have elementary school-aged children in the city of Bandung. Measurements were made using the Mindfulness in Parenting Questionnaire by McCaffrey (2015) and the Parental Stress Scale (PSS) by Berry \& Jones (1995). The results showed that mindful parenting had an effect on parenting stress $(\mathrm{r}$ square $=.152, \mathrm{p}<.05)$. The effect is that when parents have high mindful parenting behavior, the stress of parenting is low.
\end{abstract}

Keywords: Teacher, Mindful Parenting, Elementary School Parenting Stress.

\begin{abstract}
Abstrak. Mindful parenting merupakan keterampilan pengasuhan yang penuh perhatian dan kesadaran, serta menerima anak tanpa penilaian. Dengan menerapkan mindful parenting, orangtua terhindar dari melakukan pengasuhan yang kasar dan membuat tingkat stres pengasuhan orangtua berkurang. Penelitian ini bertujuan untuk melihat pengaruh mindful parenting terhadap stres pengasuhan. Guru memiliki beban yang lebih berat karena mereka harus mengurus anak dan bekerja dengan sistem yang berbeda di masa pandemi. Memiliki anak yang berada di Sekolah Dasar pun menjadi tantangan tersendiri bagi ibu, di mana mereka membutuhkan Arahan dari orangtua dan pendampingan dalam belajar. Penelitian ini menggunakan metode kausalitas dan merupakan studi populasi dengan subjek berjumlah 49 ibu yang bekerja sebagai guru sekolah dasar swasta yang memiliki anak berusia sekolah dasar di Kota Bandung. Alat ukur yang digunakan yaitu Mindfulness in Parenting Questionnaire yang disusun oleh McCaffrey (2015) dan Parental Stress Scale (PSS) yang disusun oleh Berry \& Jones (1995). Hasil penelitian menunjukkan bahwa mindful parenting memberikan pengaruh terhadap stres pengasuhan ( $\mathrm{r}$ square $.152, \mathrm{p}<.05$ ). Pengaruhnya adalah ketika orangtua memiliki perilaku mindful parenting yang tinggi, maka stres pengasuhan ibu rendah.
\end{abstract}

Kata Kunci: Guru, Mindful Parenting, Sekolah Dasar, Stres Pengasuhan. 


\section{A. Pendahuluan}

Mengasuh merupakan sebuah proses panjang yang dihadapi orangtua keetika mereka memiliki anak. Penelitian yang dilakukan Arthur Jersild dkk menunjukkan bahwa lebih banyak orangtua yang mendapatkan kesenangan saat membesarkan anak dibandingkan dengan masalah yang didapatkan saat membesarkan anak (Brooks, 2011).

Salah satu keterampilan yang mendukung orangtua dalam mengasuh yaitu mindful parenting. Duncan (2009) mendefinisikan mindful parenting sebagai seperangkat praktik atau keterampilan orangtua yang berusaha meningkatkan kesadaran dari waktu ke waktu dalam hubungan orangtua-anak (Moreira \& Canavarro, 2015). Mindful parenting mengacu pada sikap, ucapan, dan perilaku serta penampilan orangtua yang mengedepankan kesadaran/ eling dalam mengasuh buah hati mereka.

Ketika orang tua membawa praktik pengasuhan yang penuh perhatian ke dalam interaksi orang tua-anak, mereka dapat memupuk kapasitas untuk mengasuh dengan tenang, dengan konsistensi yang lebih besar, dan lebih sesuai dengan tujuan dan nilai-nilai mereka, sembari memunculkan tenor afektif yang hangat (Duncan, 2009). Pengasuhan yang penuh perhatian juga berkontribusi dalam memelihara dan membuat hubungan orang tua-anak yang lebih positif secara umum (misalnya, kepercayaan yang lebih besar dan berbagi emosional), memiliki fleksibilitas dan daya tanggap yang lebih besar dalam pertukaran dinamis hubungan orang tua-anak, penggunaan strategi pengasuhan yang lebih bijaksana dan tekanan atau stres pengasuhan yang menurun, (Duncan et al., 2009).

Stres pengasuhan dapat didefinisikan sebagai kecemasan dan ketegangan berlebih yang secara khusus terkait dengan peran orang tua dan interaksi orang tua-anak (Abidin dalam Ahern, 2004). Berry \& Jones (1995) menyatakan bahwa ketika orangtua merasakan stress pengasuhan, mereka akan cenderung mudah tersinggung, tidak mendukung anak, dan hanya memberikan sedikit kasih sayang kepada anak. Mereka juga menjadi bersikap lebih kasar, kritis, dan kaku saat menghadapi anak (Berry \& Jones, 1995). Selain itu menurut penelitian yang dilakukan oleh Belsky (1984) dan Webster-Stratton, bentuk perilaku yang ditunjukkan oleh orangtua ketika mengalami stress pengasuhan yaitu lebih banyak menolak, membatasi kegiatan anak, reaktif, serta menjadi kurang hangat terhadap anak-anak mereka (Bögels et al., 2010).

Kondisi pandemi saat ini membuat beban ibu bertambah. Sebagai guru, ibu terkadang masih harus datang ke sekolah walaupun sekolah masih dilakukan secara daring. Meskipun begitu, ibu tetap harus mendampingi anak ketika sekolah serta memenuhi kebutuhan anak suami yang bertambah dan juga harus menyusun sistem pembelajaran virtual untuk para siswanya serta melakukan penilaian.

Guru Sekolah Dasar memiliki tugas yang lebih kompleks di kondisi saat ini. Anakanak yang masih berada dalam tahapan operasional konkret membutuhkan lebih banyak arahan dari gurunya. Oleh karena itu, guru perlu benar-benar memikirkan cara agar siswa dapat tetap memahami materi meskipun pembelajaran dilakukan jarak jauh. Mereka juga harus memikirkan bentuk dan media penilaian yang mudah untuk siswa karena siswa Sekolah Dasar masih harus didampingi oleh orangtua dalam menggunakan gawai.

Pekerjaan yang dilakukan oleh guru mungkin dirasakan berbeda ketika dilakukan di tengah kondisi pandemi seperti saat ini dan bisa membuat pekerjaan ibu menumpuk. Kondisikondisi tersebut dapat menimbulkan stres apabila mereka harus melakukan kegiatan yang beragam dan multitasking (Beth, Reczek, \& Umberson, 2015; Hong et al., 2018 dalam Marliani dkk, 2020). Selain itu, berdasarkan penelitian ditemukan bahwa adanya Covid-19 ini juga memberikan dampak terkait adanya peningkatan stres pengasuhan yang memberikan peningkatan resiko pengasuhan keras atau kasar (Chung et al., 2020).

Fenomena yang terjadi menunjukkan hal yang berbeda dengan keadaan yang telah dipaparkan sebelumnya. Hal ini menjadi bertentangan bahwa seharusnya ibu yang bekerja sebagai guru sekaligus harus mengasuh anaknya serta mengurus rumah mengalami stres pengasuhan di masa pandemi ini. Fenomena yang terjadi menunjukkan bahwa guru yang sekaligus menjadi ibu tidak merasakan stres pengasuhan dan menerapkan perilaku mindful parenting. 
Berdasarkan latar belakang yang telah diuraikan, maka perumusan masalah dalam penelitian ini sebagai berikut: "Apakah terdapat pengaruh mindful parenting terhadap stres pengasuhan pada guru wanita yang memiliki anak Sekolah Dasar?". Selanjutnya, tujuan dalam penelitian ini diuraikan dalam pokok-pokok sebagai berikut:

1. Untuk mendapatkan data empiris mengenai gambaran mindful parenting pada guru wanita yang memiliki anak Sekolah Dasar di Kota Bandung.

2. Untuk mendapatkan data empiris mengenai gambaran stres pengasuhan pada guru wanita yang memiliki anak Sekolah Dasar di Kota Bandung.

3. Untuk mendapatkan data empiris mengenai pengaruh mindful parenting terhadap stres pengasuhan pada guru wanita yang memiliki anak Sekolah Dasar di Kota Bandung.

\section{B. Metodologi Penelitian}

Mindful parenting merupakan sebuah perluasan praktik mindfulness dalam konteks sosial yang berkaitan dengan hubungan orangtuaanak untuk meningkatkan secure attachment (Siegel \& Hartzell, 2003). Duncan (2009) mendefinisikan mindful parenting sebagai seperangkat praktik atau keterampilan orangtua yang berusaha meningkatkan kesadaran dari waktu ke waktu dalam hubungan orangtua-anak (Moreira \& Canavarro, 2015).

Dimensi mindful parenting pertama kali dibuat oleh Duncan (2009). Kemudian McCaffrey (2015) menyusun dimensi baru untuk mindful parenting karena merasa bahwa struktur konseptual dari mindful parenting masih tidak jelas. Dimensi yang disusun oleh McCaffrey yang menggambarkan mindful parenting yaitu Parental Self-Efficacy dan Being in the Moment with Child. Dimensi Parental Self-Efficacy merupakan dimensi yang mencerminkan sikap orangtua yang tidak reaktif dan kesadaran orangtua dalam mengasuh anak, dan bagaimana orangtua memiliki pengasuhan yang berfokus pada sebuah tujuan (McCaffrey, 2015). Dimensi Being in the moment with child merupakan dimensi yang berfokus pada anak yang mencakup perhatian yang berpusat pada keadaan saat ini dan secara sadar, pemahaman empatik pada anak dan penerimaan (McCaffrey, 2015).

Dampak dari mindful parenting sendiri yaitu: 1) Hubungan orang tua-anak yang lebih positif secara umum (misalnya, pengaruh yang lebih positif dan kurang negatif, kepercayaan yang lebih besar dan berbagi emosional) (Duncan et al., 2009). 2) Penggunaan strategi pengasuhan yang lebih bijaksana (Duncan et al., 2009) dan gaya pengasuhan yang adaptif. 3) Menunjukkan praktik pengasuhan yang lebih positif (misalnya, penguatan positif, ekspresi kehangatan dan kasih sayang, komunikasi orang tua-anak yang suportif) dan lebih sedikit praktik pengasuhan yang negatif (misalnya, pengasuhan yang reaktif dan mengganggu, disiplin yang memaksa dan tidak efektif, dan permusuhan) (Parent et al. 2016 dalam Medeiros et al., 2016). 4) Regulasi emosi yang lebih baik ketika berhubungan dengan anak mereka (Bögels et al., 2010, 2014; Duncan et al., 2009). 5) Lebih mudah dan bisa menghadapi perilaku negatif anaknya dengan tenang (Bogels et. al., 2010). 6) Dapat menangani dan menurunkan tekanan atau stres pengasuhan (Bögels et al., 2010, 2014; Duncan et al., 2009).

Stres pengasuhan dapat didefinisikan sebagai sebuah perasaan cemas dan juga ketegangan berlebih yang secara khusus berkaitan dengan peran mereka sebagai orangtua dan hubungan orang tua-anak (Abidin dalam Ahern, 2004). Berry dan Jones (1995) mengungkapkan bahwa stres pengasuhan merupakan perasaan negatif yang dihadapi orangtua seperti perasaan khawatir ketika mereka merasakan adanya kesulitan saat mengasuh anak dan berfokus pada dampak yang muncul dalam diri orang tua.

Abidin (1995) mengemukakan bahwa stress pengasuhan berkaitan dengan hubungan orangtua-anak dan terdapat tiga aspek untuk mengukur pengasuhan, yaitu The Parent Distress, The Difficult Child, The Parent-Child Dsyfunctional Interaction. Kemudian Berry \& Jones (1995) melihat bahwa aspek yang disusun oleh Abidin terlalu terbatas dan lebih banyak digunakan untuk mengukur stress pengasuhan pada orangtua yang memiliki anak dengan gangguan tertentu seperti hyperactivity dan development disabilities. Oleh karena itu, Berry \& Jones menyusun konsep stress pengasuhan yang lebih umum yang kemudian menghasilkan dua tema yaitu pengasuhan positif dan pengasuhan negatif (Berry \& Jones, 1995). 
Berry \& Jones (1995) merangkum dua tema/aspek dari Belsky et al., (Kurniadi, Atmodiwirjo, Soetikno, 2019) yaitu aspek Pleasure dan Strain. Aspek pleasure merupakan komponen-komponen positif dalam pengasuhan yang menguntungkan secara emosional, seperti cinta, kegembiraan, kesenangan serta perasaan self-enrichment dan pengembangan diri (Zelman \& Ferro, 2018). Aspek strain merupakan komponen-komponen negatif dalam pengasuhan yang melibatkan berbagai tuntutan dari berbagai sumber seperti waktu, tenaga, dan uang, serta adanya larangan untuk memiliki perasaan malu, dan berkaitan dengan kontrol (Zelman \& Ferro, 2018).

Penelitian ini menggunakan metode penelitian kuantitatif dengan desain penelitian kausalitas. Populasi penelitian ini adalah 49 guru wanita yang memiliki anak SD yang bekerja di sekolah dasar swasta di wilayah Karees Kota Bandung. Penelitian ini akan menggunakan studi populasi dimana populasi menjadi sampel.

Alat ukur yang digunakan untuk mengukur mindful parenting adalah Mindfulness in Parenting Questionnaire (MIPQ) yang disusun oleh McCaffrey (2015) dan digunakan oleh Utami et al., (2020) dengan jumlah item sebanyak 28 item. Alat ukur yang digunakan untuk mengukur stres pengasuhan adalah Parental Stress Scale yang disusun oleh Berry \& Jones (1995) dan digunakan oleh Utami et al., (2020) yang terdiri dari 18 item.

Analisis data yang digunakan dalam penelitian ini adalah analisis regresi untuk melihat pengaruh mindful parenting terhadap stres pengasuhan. Proses analisis data dibantu dengan penggunaan software SPSS 23 version.

\section{Hasil dan Pembahasan}

\section{Gambaran Mindful Parenting dan Stres Pengasuhan}

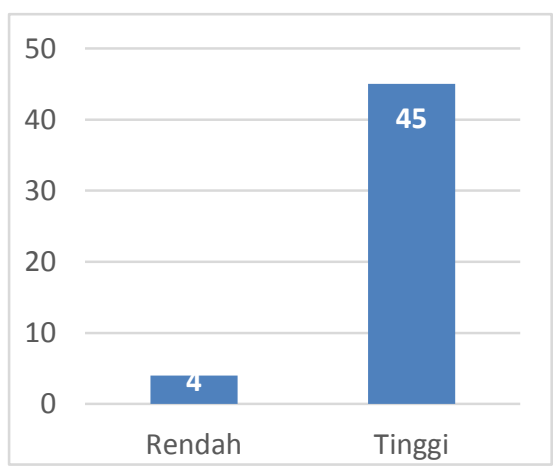

Diagram 1. Gambaran Mindful Parenting

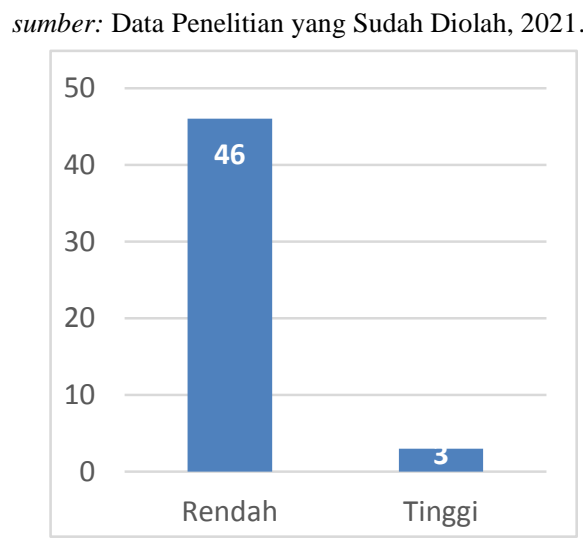

Diagram 2. Gambaran Stres Pengasuhan 
Berdasarkan data pada Diagram 1. dan 2, hasil yang ditunjukkan sejalan dengan analisis regresi dimana para guru yang memiliki skor mindful parenting yang tinggi, mereka juga memiliki skor stres pengasuhan yang rendah. Hal ini sejalan dengan riset yang dilakukan McCaffrey (2015), yang mengatakan bahwa melalui kondisi orangtua yang mindful, orangtua dapat memberikan perhatian yang positif kepada anak serta menerima keadaan anak apa adanya. Dengan perilaku dan perasaan tersebut, orangtua dapat menurunkan kondisi stres dalam pengasuhan.

Pada penelitian ini ditemukan bahwa sebagian besar subjek yaitu 45 orang memiliki skor mindful parenting yang tinggi. Oleh karena itu dapat disimpulkan bahwa Mindful Parenting pada guru wanita yang memiliki anak Sekolah Dasar tinggi. Para guru sadar dan memberikan perhatian secara penuh saat mengasuh anak mereka.

Sedangkan untuk variabel stres pengasuhan, subjek sebagian besar atau sebanyak 46 dari 49 orang memiliki tingkat stres pengasuhan yang rendah. Oleh karena itu, dapat disimpulkan bahwa stres pengasuhan pada guru wanita yang memiliki anak Sekolah Dasar rendah. Artinya, para guru dalam mengasuh anak anak mereka tidak merasakan stres yang disebabkan oleh pengasuhan yang mereka jalani. Para guru tidak menganggap bahwa mengasuh menjadi suatu tekanan tetapi mereka menganggap bahwa mengasuh menjadi hal yang menyenangkan.

\section{Pengaruh Mindful Parenting (X) terhadap Stres Pengasuhan (Y)}

Berikut adalah penelitian mengenai pengaruh mindful parenting terhadap stres pengasuhan, yang diuji menggunakan teknik analisis regresi Hasil pengujian dijelaskan pada tabel 1.

Tabel 1. Pengaruh Mindful Parenting (X) Terhadap Stres Pengasuhan (Y)

\begin{tabular}{|c|c|c|c|c|c|c|c|}
\hline Variabel & $\mathbf{r}$ & $\mathbf{t}_{\text {hitung }}$ & $\mathbf{T}_{\text {tabel }}$ & Sig. & Keputusan & $\begin{array}{c}\text { Koef } \\
\cdot \boldsymbol{\beta}\end{array}$ & $\begin{array}{c}\text { Koef. } \\
\text { Deter- } \\
\text { minasi }\end{array}$ \\
\hline $\mathrm{X}$ dan Y & .390 & -2.905 & 1.984 & .006 & Ho ditolak & -.390 & $15,2 \%$ \\
\hline
\end{tabular}

Sumber: Data Penelitian yang Sudah Diolah, 2021.

Dari tabel 1 tersebut, dapat diketahui bahwa didapatkan nilai sig. $\mathrm{t}$ sebesar 0,006 dimana nilai sig. t ini lebih kecil daripada $\alpha=0,05$. Oleh karena itu, dapat disimpulkan bahwa H0 ditolak yang berarti mindful parenting memberikan pengaruh terhadap stres pengasuhan pada guru wanita yang memiliki anak Sekolah Dasar di Kota Bandung. Hal ini sejalan dengan penelitian Gani \& Kumalasari (2019) yang menyatakan bahwa mindful parenting memiliki peran atau dalam hal ini pengaruh terhadap stres pengasuhan.

Besarnya hubungan mindful parenting dengan stres pengasuhan adalah .390. Hubungan ini termasuk kategori rendah tapi pasti menurut tabel kriteria Guilford. Koefisiensi determinasi yang didapat dari hasil perhitungan adalah $15.2 \%$. Hal ini memberikan pengertian bahwa stres pengasuhan dipengaruhi oleh variabel mindful parenting sebesar $15.2 \%$, sedangkan sisanya, $84.8 \%$, merupakan kontribusi variabel lain selain variable mindful parenting yang tidak dijelaskan di dalam penelitian ini. Pengaruh mindful parenting terhadap stres pengasuhan dapat dikatakan kecil karena besarnya pengaruh mindful parenting lebih kecil dibandingkan dengan faktor yang lainnya.

Pada analisis regresi terdapat koefisien beta yang bernilai $-0,390$. Tanda negatif di depan nilai koefisien beta menunjukkan bahwa pengaruh mindful parenting terhadap stres pengasuhan memiliki arah negatif. Artinya, jika ibu menerapkan perilaku mindful parenting, maka ibu tidak mengalami stres pengasuhan. Hal ini juga 
sejalan dengan penelitian Gani \& Kumalasari (2019) yang menyatakan bahwa adanya peran negatif mindful parenting terhadap stres pengasuhan.

Tabel 2. Tabulasi Silang Mindful Parenting (X) Dengan Stres Pengasuhan (Y)

\begin{tabular}{clccc}
\hline & & \multicolumn{2}{c}{ Mindful } & \\
& & \multicolumn{2}{c}{ Parenting } & Total \\
\cline { 3 - 4 } & & Rendah & Tinggi & \\
\hline Stres & Rendah & 2 & $\mathbf{4 4}$ & 46 \\
Pengasuhan & Tinggi & 2 & 1 & 3 \\
& Total & 4 & 45 & 49 \\
\hline
\end{tabular}

Berdasarkan tabel 2, didapatkan data bahwa terdapat 44 subjek yang memiliki tingkat mindful parenting yang tinggi dan stres pengasuhan yang rendah. Terdapat 1 subjek yang memiliki mindful parenting tinggi dan stres pengasuhan tinggi. Jumlah subjek yang memiliki mindful parenting rendah dan stres pengasuhan rendah yaitu 2 orang dan yang memiliki mindful parenting rendah dan stres pengasuhan tinggi sebanyak 2 orang. Hal ini sejalan dengan arah pengaruh yang negatif dimana subjek yang memiliki mindful parenting tinggi kebanyakan memiliki tingkat stres pengasuhan yang rendah. Begitu juga sebaliknya, ketika subjek memiliki mindful parenting rendah memiliki tingkat stres pengasuhan tinggi.

Meskipun pengaruh yang diberikan mindful parenting terhadap stres pengasuhan kecil, menerapkan perilaku mindful parenting tetap menjadi hal yang penting bagi orangtua. Dengan menerapkan perilaku mindful parenting, orangtua menjadi lebih tenang dalam mengasuh dan mampu mengontrol emosinya ketika bersama anak karena sebelum mereka melakukan sesuatu terhadap anak mereka memikirkannya terlebih dahulu. Hal ini sejalan dengan yang disebutkan oleh Bögels, Lehtonen, \& Restifo (2010) yang menyebutkan bahwa mindful parenting membuat orangtua memiliki regulasi emosi yang lebih baik saat berinteraksi dengan anak.

Orangtua yang memiliki perilaku mindful parenting cenderung lebih menyadari alasan-alasan dari tindakan yang mereka lakukan terhadap anak dan alasan anak melakukan tindakan tertentu. Mereka juga lebih mempertimbangkan perasaan mereka dan juga anak ketika ingin bertindak. Orangtua juga lebih menerima anak dan menikmati waktu kebersamaan mereka. Hal ini bisa membuat orangtua merasakan kebahagiaan dan puas dengan perannya sebagai orangtua sehingga mereka tidak merasa bahwa anak menjadi beban untuk mereka. Hal ini membantu mereka untuk terhindar dari stres pengasuhan.

\section{Kesimpulan}

Berdasarkan pembahasan dalam penelitian ini, peneliti menyimpulkan beberapa hasil penelitian sebagai berikut:

1. Para guru wanita yang memiliki anak Sekolah Dasar di Kota Bandung secara umum memiliki tingkat mindful parenting yang tinggi. Hal ini ditunjukkan dengan 91,8\% atau 45 subjek memiliki skor mindful parenting yang tinggi.

2. Para guru wanita yang memiliki anak Sekolah Dasar di Kota Bandung secara umum memiliki tingkat stres pengasuhan yang rendah. Hal ini ditunjukkan dengan 93,9\% atau 46 subjek memiliki skor stres pengasuhan yang rendah.

3. Mindful parenting memberikan pengaruh terhadap stres pengasuhan, namun pengaruh yang diberikan kecil karena mindful parenting hanya memberikan kontribusi sebesar $15,2 \%$ yang artinya sekitar $84,8 \%$ merupakan kontribusi variabel lain yang tidak dijelaskan dalam penelitian ini. 


\section{Acknowledge}

Puji dan Syukur peneliti panjatkan atas kehadirat Allah Swt. yang telah memberikan segala kenikmatan dan kemudahan. Terima kasih kepada pembimbing peneliti, Bu Makmuroh Sri Rahayu dan Teh Andhita Nurul Khasanah yang telah membimbing dan membantu peneliti serta sabar dalam menghadapi peneliti hingga akhirnya peneliti bisa sampai di tahap seperti sekarang ini. Tidak lupa terima kasih peneliti ucapkan untuk para responden yang telah bersedia membantu peneliti secara sukarela, karena tanpa bantuan dari mereka penelitian ini tidak akan bisa berjalan. Terima kasih juga untuk kedua orangtua, adik, kakek, dan nenek yang telah merawat, menyayangi, mendoakan dan mendukung peneliti hingga saat ini. Serta terima kasih untuk teman-teman sma dan kuliah yang telah memberikan banyak dukungan dan menjadi tempat berkeluh kesah peneliti selama ini. Peneliti juga mengucapkan terima kasih kepada teman-teman satu bimbingan yang sudah saling mendukung dan menyemangati satu sama lain sampai akhirnya bisa melewati tahap ini hingga selesai bersama-sama. Selain itu, terima kasih juga untuk semua pihak yang tidak bisa disebutkan satu-satu yang telah membantu peneliti hingga sampai ke tahap ini. Semoga kebaikan semuanya bisa dibalas oleh Allah Swt. dan selalu diberikan kesehatan dan kelancaran di dalam segala urusannya.

\section{Daftar Pustaka}

[1] Ahern, L.S. (2004). Psychometric properties of the parenting stress index- short form (Thesis). North Carolina State University: Department of Psychology.

[2] Berry, J. O., \& Jones, W. H. (1995). The parental stress scale: Initial psychometric evidence. Journal of Social and Personal Relationships, 12(3), 463-472. https://doi.org/10.1177/0265407595123009

[3] Bögels, S. M., Hellemans, J., van Deursen, S., Römer, M., \& van der Meulen, R. (2014). Mindful parenting in mental health care: Effects on parental and child psychopathology, parental stress, parenting, coparenting, and marital functioning. Mindfulness, 5(5). https://doi.org/10.1007/s12671-013-0209-7

[4] Bögels, S. M., Lehtonen, A., \& Restifo, K. (2010). Mindful Parenting in Mental Health Care. Mindfulness, 1(2). https://doi.org/10.1007/s12671-010-0014-5

[5] Brooks, J. 2011. The Process of Parenting 8th edition. Pustaka Pelajar

[6] Duncan, L. G., Coatsworth, J. D., \& Greenberg, M. T. (2009). A Model of Mindful Parenting: Implications for Parent-Child Relationships and Prevention Research. Clinical Child and Family Psychology Review, 12(3). https://doi.org/10.1007/s10567009-0046-3

[7] McCaffrey, S. (2015). Mindfulness In Parenting Questionnaire (MIPQ): Development and validation of a measure of mindful parenting (Disertasi, Nova Southeastern University, 2015). Available at: h6ps://nsuworks.nova.edu/cps_stuetd/81

[8] Moreira, H., \& Canavarro, M. C. (2015). Individual and gender differences in mindful parenting: The role of attachment and caregiving representations. Personality and Individual Differences, 87. https://doi.org/10.1016/j.paid.2015.07.021

[9] Siegel, D. J., \& Hartzell, M. (2003). Parenting from the inside out: how a deeper selfunderstanding can help you raise children who thrive. New York: J.P. Tarcher/Putnam.

[10] Zelman, J. J., \& Ferro, M. A. (2018). The Parental Stress Scale: Psychometric Properties in Families of Children With Chronic Health Conditions. Family Relations, 67(2). https://doi.org/10.1111/fare.12306 